\title{
SIMULIUM DAMNOSUM, NATURALLY INFECTED WITH ONCHOCERCA VOLVULUS IN SOUTH-WEST ETHIOPIA ${ }^{1}$
}

\author{
Ikuo Tanaka 2 , Yoshisato Inoue ${ }^{3}$, Isao Tada ${ }^{4}$, Isao Inamoto ${ }^{5}$ \\ and TeFERra Wonde 6
}

Received for publication 19 July 1973

\begin{abstract}
The existence of onchocerciasis in Ethiopia, especially in its South-Western Region was known. The naturally infected Simulium has not been reported in the region, though there has been reported the existence of $S$. damnosum, $S$. woodi etc. which were identified as the vectors of this disease in other parts of Africa. The authors obtained a number of Onchocerca volvulus from $S$. damnosum collected by biting-catch method in the field in August and November, 1971. Dissection was made on the 975 Simulium out of about 1000 caught at the riverside of Gojeb and those caught at Didessa riverside. The infection rate ranged from 10.2 to $12.9 \%$ in the former and 20.0 to 40.6 in the latter. The sausage type was most frequently found and the late stage type was detected in $11 \%$ of Simulium. An evidence was given that $S$. damnosum is the main vector of onchocerciasis in Ethiopia, since this species formed an absolute majority of the flies collected by biting catch and no filaria was detected in the other species.
\end{abstract}

The existence of onchocerciasis in Ethiopia was initially ascertained in 1939 at Bonga, Kefa Province, and the collection record on Simulium damnosum was made by the same author (Giaquinto, M. 1939).

Oomen, A. P. (1969) collected S. damnosum and S. woodi, and suggested that $S$. damnosum might be the vector of this disease in the south-west Ethiopia surveyed.

Although $S$. damnosum has been incriminated to be one of the potential vectors of onchocerciasis in Ethiopia, naturally infected S. damnosum has not yet been reported, so far as we are aware.

In order to clarify the vector species of this disease, we visited the endemic area of South-west Ethiopia in 1971, and made attempts to check infected adult black flies.

This paper is a brief report on the discovery of naturally infected $S$. damnosum with Onchocerca volvulus in the area.

1 The contents of this paper was preliminarily presented at the 24th Annual Meeting of the Japan Society of Sanitary Zoology, Okayama, 3 April 1972. 2 Division of Pest Control, Japan Environmental Sanitation Center, Kawasaki, Japan. 3 Dept. of Medical Zoology, National Institute of Health, Tokyo, Japan. 4 Dept. of Medical Zoology, Kanazawa Medical University, Uchinada, Ishikawa, Japan. 5 Dept. of Parasitology, Institute for Tropical Medicine, Nagasaki University, Nagasaki, Japan. 6 Dept. of Medical Zoology, Imperial Central Laboratory \& Research Institute, Addis Ababa, Ethiopia. 


\section{Materials And Methods}

(a) Date of the survey and collection sites (Fig. 1)

March 18-25, 1971: riverside of Gojeb, Kefa Province

July 31-August 15: riverside of Didessa and adjacent plateau $1 \mathrm{~km}$ from the riverside, Ilubabor Province

November 15-18 : riverside of Gojeb and Didessa

(b) Catching method for the adult black flies

Collection was made by two or three volunteers seated on a rock or the ground at the individual sites. All the black flies settled on the naked parts of the body were caught using a sucking tube every 30 minutes from sun rise to sun set.

(c) Treatment and dissection of the flies

Collected flies were anesthetized with ether and, in every 60 minutes, were gathered in batches in one small glass tube. After identification, the flies were dissected in a droplet of physiologic saline solution on a slide glass under a dissecting microscope in order to find the parasite.

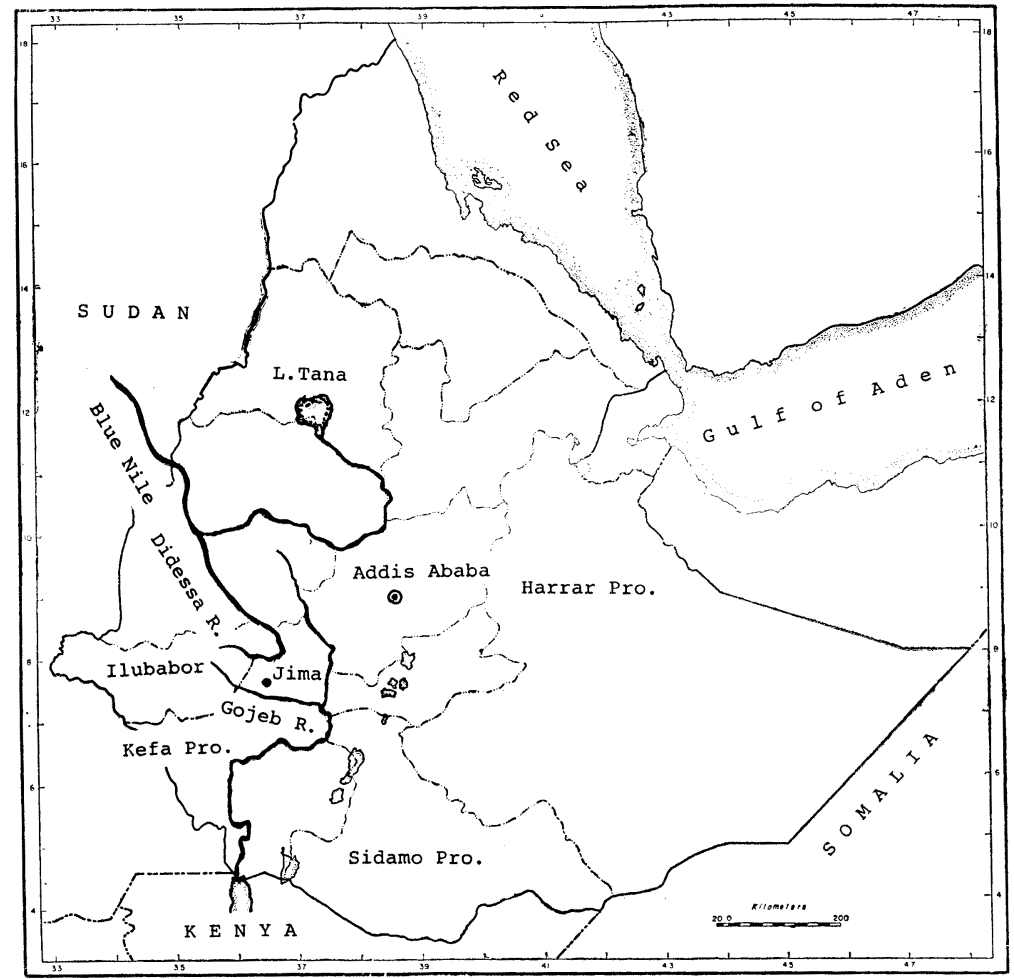

Fig. 1 Map of Ethiopia showing the rivers where $S$. damnosum were collected. 


\section{REsults}

As shown in Table 1 , the infection rate of $S$. damnosum with the larvae of $O$. volvulus ranged from 20.0 to $40.6 \%$ at the several collection sites in Didessa area and ranged from 10.2 to $12.9 \%$ at the Gojeb riverside. The other species of black fly had not been found to be infected with filarial worms.

TABLE 1 Number of the naturally infected Simulium damnosum with the filarial worm, Onchocerca volvulus

\begin{tabular}{|c|c|c|c|c|c|c|}
\hline & & \multirow{2}{*}{\multicolumn{2}{|c|}{$\begin{array}{c}\text { Gojeb } \\
\text { riverside }\end{array}$}} & \multicolumn{3}{|c|}{ Didessa } \\
\hline & & & & \multicolumn{2}{|c|}{ riverside } & \multirow{2}{*}{$\begin{array}{l}\text { plateau } \\
\text { Aug. } 15\end{array}$} \\
\hline & & Mar. 24 & Nov. 18 & Aug. 13 & Nov. 15 & \\
\hline \multirow{3}{*}{\multicolumn{2}{|c|}{$\begin{array}{l}\text { No. flies collected } \\
\text { No. flies infected } \\
\text { Infection rate \% }\end{array}$}} & 85 & 127 & 726 & 5 & 32 \\
\hline & & $11(-)$ & $13(8)$ & $237(96)$ & $1(0)$ & $13(4)$ \\
\hline & & 12.9 & 10.2 & 32.6 & 20.0 & 40.6 \\
\hline \multirow{7}{*}{ 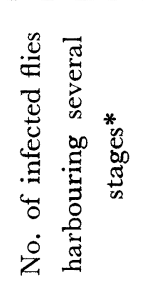 } & $\mathrm{m}$ & - & 2 & 12 & 0 & 2 \\
\hline & $\mathrm{s}$ & - & 3 & 116 & 1 & 6 \\
\hline & 1 & - & 7 & 64 & 0 & 3 \\
\hline & $\mathrm{m}+\mathrm{s}$ & - & 0 & 13 & 0 & 1 \\
\hline & $\mathrm{m}+1$ & - & 0 & 2 & 0 & 0 \\
\hline & $\mathrm{s}+1$ & - & 1 & 29 & 0 & 0 \\
\hline & $m+s+1$ & - & 0 & 1 & 0 & 1 \\
\hline
\end{tabular}

* Stage type of the larvae

$\mathrm{m}$ : microfilaria type

s: sausage type

1: late stage type

-: each stages not checked

Parenthesis: total flies possessing late stage type worm

In adult $S$. damnosum dissected, all the three developmental stages of $O$. volvulus i.e., microfilaria type, sausage type and late stage type were found. Of these three types, the sausage type was most abundant and this was followed by the late stage type and then microfilaria type. Finding the black flies possessing the late stage type is especially important from the epidemiological viewpoint.

In August 1971, at the Didessa riverside, out of 237 infected S. damnosum, 96 harboured the late stage worms. The body length measured ranged from $300 \mu$ to $700 \mu$.

Regarding the frequency of harbouring worms in one dissected fly, usually only one type was recognized. In a few case, however, two or three types of filarial larvae were simultaneously found.

The highest number of the sausage type larvae recognized was 51, while that of the late stage type, 17.

Some smeared specimens were identified as the larval stage of $O$. volvulus by Dr. R. L. Muller, of London School of Tropical Medicine and Hygiene. 


\section{Discussion}

It has been already known that onchocerciasis is endemic in South-west Ethiopia (Cohen, L. B. 1960, Oomen, A. P. 1969, Iwamoto, I. et al. 1973). There is a general agreement that $S$. damnosum and $S$. neavei complex are the main vector of onchocerciasis in many tropical regions in Africa (De Meillon, B. 1957). Oomen, A. P. (1969), in particular, collected $S$. damnosum and $S$. woodi, and postulated that $S$. damnosum might be the vector of onchocerciasis in Ethiopia. Ogata, K. et al. (1970) reported that they collected seven anthropophilic Simulium species in Ethiopia and $S$. damnosum was recognized as the most common one.

Through our study, naturally infected $S$. damnosum with Onchocerca volvulus was abundantly found in natural population, whereas the other black fly species were found free from filarial larvae.

Thus, the present study brings an evidence that $S$. damnosum is the main vector of onchocerciasis in South-west Ethiopia, yet no possibility is denied if onchocerciasis could also be transmitted by the other Simulium species in this area. It is hoped that further studies will throw more light on this problem.

\section{Acknowledgement}

Acknowledge is made to the support of Dr. T. Aseffa, the Exdirector, Imperial Central Laboratory \& Research Institute, Addis Ababa and Dr. S. Asahina, Chief of Medical Entomology, National Institute of Health, Tokyo.

We also wish to thank to Dr. R. L. Muller, of the London School of Tropical Medicine and Hygiene, for confirming the identification of the filarial larvae in our black fly specimens.

This work was supported by Overseas Technical Cooperation Agency, Japan.

\section{References}

1) Cohen, L. B. (1960): Idiopathic lymphoedema of Ethiopia and Kenya, East Africa Med. J., 37, 53

2) De Meillon, B. (1957): Bionomics of the vectors of onchocerciasis in the Ethiopian geographical region. Bull. Wld Hlth Org., 16, 509-522

3) Iwamoto, I., Tada, I. and Wonde, T. (1973): Clinical manifestation of onchocerciasis in endemic foci of Ilubabor Province, Ethiopia, Trop. Med., 15, 36-45

4) Muller, R. L. (1972): Personal communication to Dr. I. Tada

5) Ogata, K., Takahashi, M. and Ohse, T. (1970): Distribution and epidemiology of black flies in Ethiopia (Summary in Japanese), Jap. J. Sanit. Zool., 21, 134

6) Oomen, A. P. (1969): Studies on onchocerciasis and elephantiasis in Ethiopia, 115, De Erven F. Bohn, N. V., Haarlem

7) Tanaka, I. and Inoue, Y. (1972): Simulium damnosum and its feasibility of the vector of onchocerciasis in Ethiopia (Summary in Japanese), Jap. J. Sanit. Zool., 22, 250 
エチオピア南西部において Onchocerca volvulus 自然感染の見られた

Simulium damnosum

田中生男 ${ }^{1}$ ・井上義郷 ${ }^{2}$ ・多田 功 ${ }^{3}$ ・岩本 $\quad$ 功 ${ }^{4} ・$ テェラ・ウオンデ5

エチオピアにおいては，とくに，その南西部にオンコセルカ病が存在することが知られ，また，他の アフリカ地域で，そのベクターと判明している，Simulium damnosum, S. woodi などのブユが生息す ることが確認されていたが，自然感染ブユは発見されなかった。筆者らは1971年同国に滞在し，8月と 11月に行なった biting catch によって得た，野外の S. damnosum から，多数の Onchocerca volvulus を得た。

Gojeb, Didessa 両河岸から得た個体約 1000 のうち，975 個体につレて解剖を行をった結果，前者で 10.2 12.9\%，後者で $20.0 \sim 40.6 \%$ の陽性個体を得た。ブユ体内における O. volvulus の発育段階別 では, sausage type のものが最も多かったが, 約 $11 \%$ の個体が発育終期のものを保有していた。

biting catchによって採集されたブユは，活とんどが S. damnosum であったこと，および，他種の ブユからは全くフイラリアが発見されなかったことから，エチオピアにおいても，S. damnosum がオ ンコセルカ病の主要媒介種であるという確証を得た。

1 日本環境衛生センター 環境生物部 2 国立予防衛生研究所 衛生昆虫部 3 金沢医科大学 医動物学教室 4 長崎大学熱帯医学研究所 奇生虫学部門 5 エチオピア帝国中央研究所 医動 物学部門 